Original Research

\title{
Kecemasan, Kesepian dan Persepsi terhadap Perkawinan Siri
}

\author{
Reny Firsty Oktasari ${ }^{1 *}$, Elly Yuliandari ${ }^{1}$ \\ ${ }^{1}$ Fakultas Psikologi, Universitas Surabaya, Raya Kalirungkut Surabaya, 60293-Indonesia \\ * corresponding author: renyfirsty.5110155@gmail.com
}

Abstract - Perceptions of the siri marriage is purpose to a form of marriage that is secretly and undocumented, which is involving cognitive and affective aspects. The factors that affect the perception of the siri marriage is the experienced, motivation, individual thinking style also individuals believe about siri marriage itself. Widow in early adulthood is still in the developmental tasks that require them to choose a partner and have a family. So the task of these developments become social expectations. Widow automatically has consequences for the dissolution of biological, sexual and psychological needs which can make individuals may feel anxiety and loneliness. The purpose of this study was to determine the relationship between anxiety and loneliness to the perception of siri marriage to the widow. The number of subjects were 30 widows in the age range 20 to 40 years, both divorced and the spouse died, who working in Surabaya and Sidoarjo, and also have the desire to remarriage. The sampling technique used was snowball sampling. Correlation test results showed no association between anxiety and perception of marriage siri ( $r=0569 ; p$ =0108); there is no connection between loneliness and perception of marriage siri $(r=0.279 ; p=0.204)$.

Keywords: anxiety, loneliness, perception, siri marriage

\begin{abstract}
Abstrak - Persepsi terhadap perkawinan siri merupakan pemaknaan terhadap suatu bentuk perkawinan rahasia yang tidak tercatat dengan melibatkan aspek kognitif dan afektif. Faktor yang mempengaruhi persepsi terhadap perkawinan siri selain perasaan yang dialami, motivasi, pengalaman masa lalu, gaya berpikir individu, juga dipengaruhi oleh believe individu tentang perkawinan siri itu sendiri. Janda pada masa dewasa awal masih dalam tugas perkembangan yang menuntut mereka untuk memilih pasangan dan memiliki keluarga. Sehingga tugas perkembangan tersebut menjadi social expectations. Status janda secara otomatis membawa konsekwensi terputusnya pemenuhan kebutuhan biologis, seksual dan psikologis yang dapat membuat individu baik cerai hidup maupun cerai mati dapat merasakan kecemasan dan kesepian. Tujuan dari penelitian ini adalah untuk mengetahui adanya hubungan antara kecemasan dan kesepian dengan persepsi terhadap perkawinan siri pada janda. Jumlah subjek sebanyak 30 orang janda dalam rentang usia 20 hingga 40 tahun, baik cerai hidup maupun cerai mati yang bekerja di Surabaya dan Sidoarjo serta memiliki keinginan untuk melakukan perkawinan kembali pasca perceraian. Tehnik sampling yang digunakan adalah snowball sampling. Hasil uji korelasi menunjukkan tidak ada hubungan antara kecemasan dan persepsi terhadap perkawinan siri $(r=0.569 ; p=0.108)$; tidak ada hubungan antara kesepian dan persepsi terhadap perkawinan siri $(r=0.279 ; p=$ 0.204).
\end{abstract}

Kata kunci: kecemasan, kesepian, persepsi, perkawinan siri

\section{PENDAHULUAN}

Perkawinan siri di Indonesia dilakukan oleh berbagai kalangan, baik dari masyarakat sipil, artis, hingga pejabat pemerintah. Ditambah lagi fenomena perkawinan siri online di awal tahun 2015 yang marak dijadikan sebagai ajang bisnis dan masih berlangsung hingga saat ini. Badan Litbang dan Diklat Kementerian Agama melakukan sensus di sembilan kabupaten di Indonesia yang banyak melakukan perkawinan siri dan perkawinan di bawah umur. Sembilan kabupaten itu berada di propinsi Jawa Timur, Jawa Barat, Nusa Tenggara Barat, Kalimantan Selatan dan Yogyakarta (Sari 2012). Arom Elmina (pengamat hukum pidana Universitas Indonesia) mengatakan bahwa perkawinan siri seperti gunung es, tampak sedikit di permukaan, tapi banyak praktiknya yang tidak tampak karena sifat khas dari perkawinan ini adalah rahasia (Wijaya 2015).

Perkawinan siri adalah perkawinan yang memenuhi hukum Islam (ijab, qabul, dua orang mempelai, wali nikah dan dua saksi) dan dianggap sah oleh masyarakat (Fathudin \& Fitria 2015); yang pelaksanaannya tanpa melalui pencatatan pada lembaga yang berwenang sehingga tidak memiliki kekuatan hukum (Pujihartati 2010). Berdasarkan definisi tersebut, maka definisi perkawinan siri yang digunakan dalam penelitian ini adalah perkawinan yang memenuhi syarat kawin pada agama Islam, namun tidak tercatat di lembaga yang berwenang. Hak dan kewajiban suami istri dalam kawin siri yang memenuhi syarat nikah dalam Islam sama dengan kawin resmi, namun memiliki dampak hukum karena tidak tercatat pada lembaga yang 
berwenang (Luthfi \& Luthfy 2010). Hal-hal yang membedakan antara kawin siri dengan kawin resmi adalah tidak dicatat dalam dokumen resmi negara, tidak ada perlindungan hukum negara, proses perceraian tanpa melalui sidang pengadilan, dan tidak ada perlindungan negara terhadap hak waris.

Dalam masyarakat, wanita yang sudah tidak lagi memiliki suami dikenal dengan istilah janda. Janda adalah wanita yang telah mengalami perceraian, baik yang disebabkan cerai hidup maupun cerai mati (Fachrina \& Anggraini 2007). Janda cerai hidup mengalami kegagalan penyesuaian perkawinan yang telah mencapai titik puncaknya, sehingga sudah tidak mampu lagi mencari jalan keluar dari masalah yang ada pada perkawinan mereka dan memilih perceraian sebagai jalan keluar (Hurlock 1996). Martin-Matthews mengatakan bahwa janda yang ditinggal mati, kematian pasangan merupakan pengalaman yang paling traumatis karena kejadian tersebut bukanlah pilihannya (Cavanaugh \& Blanchard-Fields 2011).

Terbiasa menjalani hidup berdua dengan pasangan membuat seseorang merasa kosong ketika pasangan yang lain tidak ada lagi di sisinya. Hasil penelitian Hetherington menyatakan bahwa peristiwa perceraian menimbulkan ketidakstabilan emosi, mengalami rasa cemas, tertekan serta sering marah-marah, dan ibu adalah pihak yang paling pahit merasakan akibatnya ketika menghadapi kemelut perceraian (Dagun 2002). Mc Lanahan dan Adams menyatakan bahwa peningkatan tekanan psikologis akan dialami orang tua tunggal secara konsisten (Hope, Power, \& Rodgers 1999). Tidak lagi memiliki suami dapat menimbulkan masalah-masalah pasca-perceraian seperti masalah ekonomi, masalah praktis kegiatan rumah tangga sehari-hari, masalah psikologis, masalah emosional, masalah sosial, masalah kesepian, masalah pembagian tanggung jawab pengasuhan anak, masalah seksual, dan masalah perubahan konsep diri (DeGenova 2008). Dari beberapa pernyataan tersebut dapat disimpulkan bahwa, janda memiliki kecenderungan untuk mengalami tekanan psikologis, salah satunya adalah kecemasan menghadapi kemungkinan masalah yang timbul pasca-perceraian.

Kecemasan adalah ketakutan, kegelisahan dan ketegangan yang merupakan reaksi dari ancaman ataupun konflik yang dialami (Powell 1983). Dalam pandangan Freud, kecemasan memiliki fungsi sebagai sinyal bahwa bahaya mungkin sedang mendekat (Powell 1983). Kecemasan merupakan suatu pernyataan subjektif ketika menyadari bahwa dirinya berada dalam ancaman (Spielberger \& Sarason 1989). Yang dimaksud bahaya atau ancaman di sini adalah sesuatu yang membuat individu takut kehilangan sesuatu yang berharga dari dirinya atau dari luar dirinya.

Pada umumnya, tingkat kecemasan tiap individu berbeda-beda, tergantung pada situasi yang dihadapi. Spielberger membagi kecemasan menjadi dua, yaitu: state anxiety dan trait anxiety (Powell, 1983). Dikatakan sebagai state anxiety jika seseorang merasa terancam ketika menghadapi situasi yang sulit dalam menjalani hidupnya. Dikatakan sebagai trait anxiety ketika seseorang mempersepsikan situasi lingkungan yang mengancam dirinya, padahal secara objektif tidak membahayakan, dengan kata lain adalah pembawaan seseorang yang pencemas. Penelitian ini lebih fokus pada state anxiety, yaitu kecemasan yang dirasakan janda saat menghadapi berbagai kemungkinan kesulitan hidup pasca-perceraian.

Hilangnya pasangan dalam menjalin keintiman, berkurangnya dukungan dan hilangnya pemenuhan kebutuhan seksual pada janda juga dapat menjadi pemicu munculnya kesepian. Kesepian ditemukan memiliki korelasi positif terhadap janda dan individu yang mengalami kesulitan ekonomi (Singh \& Kiran 2013). Menurut Utz, Reidy, Carr, Nesse, dan Wortman, menyandang predikat janda membuat individu harus mengatasi hilangnya hubungan intim selamanya, membentuk identitas baru sebagai orang yang belum menikah, dan belajar untuk mengelola rutinitas sehari-hari yang dulunya dilakukan berdua dengan pasangan (dalam Pudrovska \& Carr 2008). Lebih lanjut Fischer dan Philip menjelaskan bahwa wanita akan rentan terhadap kesepian apabila ikatan intim atau pernikahan tersebut mengurangi akses mereka pada jaringan sosial yang lebih luas (Miller, Perlman, \& Brehm 2007).

Menurut Sullivian, kesepian adalah respon dari kurangnya hubungan yang dapat membuat individu berbagi perasaan, cerita atau hal lain dengan individu di luar dirinya (dalam 
Peplau \& Perlman, 1982). Perasaan kesepian akan dirasakan setelah perceraian terjadi (DeGenova, 2008). Begitu juga dengan pernyataan Perlman dan Peplau; Rubeinstein dan Shaver, bahwa kesepian lebih merupakan reaksi terhadap kehilangan hubungan perkawinan (marital relationship) dan ketidakhadiran dari pasangan suami/istri pada diri seseorang (dalam Miller et al. 2007). Lebih lanjut Shaver dan Peplau menyatakan bahwa salah satu jenis perasaan yang dirasakan oleh orang yang kesepian adalah merasa desperate (pasrah). Perasaan pasrah ini merupakan perasaan putus asa, kehilangan harapan serta perasaan yang sangat menyedihkan sehingga mampu melakukan tindakan nekat, yaitu tindakan yang kurang memedulikan bahaya bagi diri sendiri maupun orang lain (Miller et al., 2007).

Banyak orang dewasa yang mencoba memecahkan masalah penyesuain diri pascaperceraian dengan cara segera melakukan remarriage (Hurlock 1996). Menurut penelitian Ganong dan Coleman, dua dari tiga wanita yang bercerai melakukan remarriage, setengahnya melakukan remarriage setelah tiga tahun perceraian (dalam Crawford 2017). Pernyataan yang serupa juga dikemukakan oleh Hurlock, menurut laporan yang ada hampir $75 \%$ orang-orang yang cerai melakukan remarriage dalam waktu lima tahun (Hurlock 1996). Di antara pelaku remarriage, terdapat sebagian orang yang memutuskan kawin secara sah dan diakui oleh hukum, sebagian lagi memutuskan untuk kawin secara siri. Data tentang jumlah pelaku perkawinan siri yang dilakukan oleh janda tidak dapat ditemukan penulis karena perkawinan siri tidak tercatat dan dirahasiakan.

Untuk mengetahui kecenderungan sikap pada janda, peneliti menggunakan persepsi terhadap perkawinan siri yang merupakan reaksi individu terhadap stimulus yang bersifat khas (dalam hal ini perkawinan siri) yang dipengaruhi oleh faktor internal seperti suasana hati dan motivasi, serta faktor eksternal seperti pembelajaran individu yang kemudian akan mengatur kecenderungan sikap dan perilaku individu terhadap suatu objek (Atkinson, Atkinson, Smith, \& Bem 1990).

Psikologi Gestalt meyakini bahwa apa yang dialami individu akan memengaruhi segala sesuatu yang lain di dalam diri individu tersebut. Misalnya, dunia akan dipandang berbeda oleh seseorang yang jempolnya terjepit pintu atau sedang sakit diare. Lebih lanjut dijelaskan bahwa ketika individu berhadapan dengan sebuah masalah, akan muncul keadaan ketidakseimbangan kognitif yang mengandung unsur motivasional sehingga menyebabkan organisme berusaha untuk mendapatkan kembali keseimbangan sistem mentalnya (Hergenhahn \& Olson 2008).

Berdasarkan pemaparan dan temuan peneliti, maka pertanyaan tentang kecemasan, kesepian dan persepsi terhadap perkawinan siri lebih tepat diajukan kepada para janda untuk mengungkapkan hubungan antara kecemasan dan kesepian dengan persepsi terhadap perkawinan siri. Dengan demikian, hipotesis pada penelitian ini adalah :

$\mathrm{H} 1$ : Semakin tinggi tingkat kecemasan pada janda akan diikuti dengan tingkat persepsi terhadap perkawinan siri yang semakin positif.

$\mathrm{H} 2$ : Semakin tinggi tingkat kesepian pada janda akan diikuti dengan tingkat persepsi terhadap perkawinan siri yang semakin positif.

\section{METODE}

Penelitian ini merupakan penelitian kuantitatif, yaitu dengan melakukan analisis korelasi antara kecemasan dan kesepian dengan persepsi terhadap perkawinan siri pada janda dalam tahapan dewasa awal. Variabel dalam penelitian ini terdiri atas dua variabel bebas, yakni kecemasan dan kesepian. Sementara variabel terikat pada penelitian ini adalah persepsi terhadap perkawinan siri.

Subjek penelitian ini adalah janda dengan rentang usia 20-40 tahun, baik cerai hidup maupun cerai mati, memiliki keinginan untuk melakukan remarriage, bekerja dan bertempat tinggal di Surabaya dan Sidoarjo. Dalam pelaksanaannya, jumlah responden sebanyak 35 orang, namun jumlah sampel yang diteliti sebanyak 30 responden. Hal tersebut dikarenakan dua di antaranya tidak mengembalikan kuesioner, dan tiga di antaranya tidak memiliki keinginan untuk melakukan remarriage, sehingga digugurkan oleh peneliti. 
Reny, F.O., et al., Kecemasan, Kesepian dan Persepsi terhadap Perkawinan Siri, KELUWIH: Jurnal Sosial dan Humaniora, Vol. 1(2), 93-101, Oktober 2020

Pengumpulan data dilakukan dengan menggunakan kuesioner yang berisikan informed consent, data demografis, angket terbuka dan angket tertutup. Variabel kecemasan menggunakan State Anxiety Inventory yang dimodifikasi dengan kecemasan yang dihadapi janda menurut Dariyo (2008). Sedangkan kuesioner Trait Anxiety Inventory digunakan sebagai data pendukung, untuk memastikan bahwa responden pada penelitian ini murni mengalami kecemasan yang sedang dihadapi dan tidak memiliki sifat cemas bawaan. Variabel kesepian menggunakan kuesioner yang disusun sendiri oleh peneliti, mengacu pada penelitian Lopata (dalam Miller et al. 2007) tentang perasaan yang muncul pada janda ketika merasa kesepian. Sedang variabel persepsi terhadap perkawinan siri menggunakan kuesioner yang disusun sendiri oleh peneliti berdasarkan fungsi sosial perkawinan menurut Stephens dengan tujuan untuk mengetahui apakah bagi janda, perkawinan siri dianggap memiliki fungsi sosial yang sama dengan perkawinan resmi pada umumnya (Saxton 1986).

Uji reliabilitas menggunakan CITC (Corrected Item Total Correlation) yang menggunakan nilai Alpha Cronbach sebagai acuan. Hasil uji reliabilitas tersebut menunjukkan kuesioner kecemasan memiliki nilai alpha sebesar 0,955; kuesioner kesepian memiliki nilai alpha sebesar 0,875; dan kuisioner persepsi terhadap perkawinan siri memiliki nilai alpha sebesar 0,966 . Selanjutnya dilakukan proses analisis data yang terbagi dalam dua bagian, yaitu analisis univariat dan analisis bivariat. Analisis univariat bertujuan untuk mendeskripsikan variabel- variabel penelitian, meliputi kecemasan, kesepian dan persepsi terhadap perkawinan siri dengan menggunakan tabel distribusi frekuensi dan statistik deskriptif. Analisis bivariat bertujuan untuk mengetahui korelasi antara kecemasan, kesepian dan persepsi terhadap perkawinan siri pada janda.

HASIL

Tabel 1

Distribusi Frekuensi Variabel Penelitian

\begin{tabular}{lcccccccc}
\hline & & \multicolumn{7}{c}{ Frekuensi dan Persentase } \\
Variabel & Mean & SD & $\begin{array}{l}\text { Sangat } \\
\text { Tinggi }\end{array}$ & Tinggi & Sedang & Rendah & $\begin{array}{c}\text { Sangat } \\
\text { rendah }\end{array}$ & Jumlah \\
\hline Kecemasan & 47,50 & 9,50 & 0 & $4(13,3 \%)$ & $8(26,7 \%)$ & $14(46,7 \%)$ & $4(13,3 \%)$ & 30 \\
Kesepian & 37,50 & 7,50 & 0 & $8(26,7 \%)$ & $13(43,3 \%)$ & $7(23,3 \%)$ & $2(6,7 \%)$ & 30 \\
$\begin{array}{l}\text { Persepsi } \\
\text { terhadap } \\
\text { perkawinan } \\
\text { siri }\end{array}$ & 77,50 & 15,50 & 0 & $4(13,3 \%)$ & $10(33,3 \%)$ & $13(43,3 \%)$ & $3(10 \%)$ & 30 \\
\hline
\end{tabular}

Berdasarkan tabel di atas, diketahui bahwa Kecemasan pada subjek penelitian berada pada kategori rendah (46.7\%) dan sedang (26.7\%); Kesepian berada pada kategori sedang (43.3\%) dan tinggi (26.7\%); dan Persepsi terhadap perkawinan siri berada pada kategori rendah (43.3\%) dan sedang (33.3\%).

Tabel 2

Uji Hubungan Antara Kecemasan Dengan Persepsi Terhadap Perkawinan Siri

\begin{tabular}{lccc}
\hline \multicolumn{1}{c}{ Variabel } & $\begin{array}{c}\text { Spearman Correlation } \\
\text { Coefficient }\end{array}$ & Sig & Status \\
\hline $\begin{array}{l}\text { Kecemasan-Persepsi terhadap } \\
\text { Perkawinan Siri }\end{array}$ & 0,108 & 0,569 & Tidak ada hubungan \\
\hline
\end{tabular}


Reny, F.O., et al., Kecemasan, Kesepian dan Persepsi terhadap Perkawinan Siri, KELUWIH: Jurnal Sosial dan Humaniora, Vol. 1(2),

Berdasarkan tabel tersebut, dapat diketahui nilai Spearman Correlation Coefficient sebesar $0.108(<0.3)$ dan nilai sig. sebesar 0.569 (>0.05). Dapat disimpulkan bahwa tinggi atau rendahnya tingkat kecemasan tidak diikuti dengan naik atau turunnya persepsi terhadap perkawinan siri.

Tabel 3

Uji Hubungan Antara Kesepian Dengan Persepsi Terhadap Perkawinan Siri

\begin{tabular}{lccc}
\hline \multicolumn{1}{c}{ Variabel } & $\begin{array}{c}\text { Spearman Correlation } \\
\text { Coefficient }\end{array}$ & Sig & Status \\
\hline $\begin{array}{l}\text { Kesepian-Persepsi terhadap } \\
\text { Perkawinan Siri }\end{array}$ & 0,204 & 0,279 & $\begin{array}{l}\text { Tidak ada } \\
\text { hubungan }\end{array}$ \\
\hline
\end{tabular}

Berdasarkan tabel tersebut, dapat diketahui nilai Spearman Correlation Coefficient sebesar $0.204(<0.3)$ dan nilai sig. sebesar 0.279 (>0.05). Dapat disimpulkan bahwa tinggi atau rendahnya tingkat kesepian tidak diikuti dengan naik atau turunnya persepsi terhadap perkawinan siri.

Tabel 4

Hasil Uji Chi Square

\begin{tabular}{clcc}
\hline No & \multicolumn{1}{c}{ Variabel } & p-Value & Status \\
\hline 1 & $\begin{array}{l}\text { Persepsi terhadap perkawinan Siri - } \\
\text { Kesediaan melakukan kawin siri }\end{array}$ & 0,000 & Ada asosiasi \\
2 & $\begin{array}{l}\text { Jumlah anak yang dimiliki - kesediaan } \\
\text { melakukan }\end{array}$ & 0,019 & Ada asosiasi \\
3 & $\begin{array}{l}\text { Jenis dukungan yang didapatkan - } \\
\text { kesediaan melakukan kawin siri }\end{array}$ & 0,015 & Ada asosiasi \\
\hline
\end{tabular}

Berdasarkan tabel di atas, diketahui bahwa baik persepsi terhadap perkawinan siri, jumlah anak yang dimiliki, dan jenis dukungan yang didapatkan subjek penelitian memiliki asosiasi dengan kesediaan melakukan kawin siri ( $p$-value $<0.05)$.

Tabel 5

Tabulasi Silang Antara Persepsi Terhadap Perkawinan Siri Dengan Kesediaan Melakukan Perkawinan Siri

\begin{tabular}{lllll}
\hline $\begin{array}{l}\text { Persepsi } \\
\text { terhadap } \\
\text { Perkawinan Siri }\end{array}$ & Tidak bersedia & $\begin{array}{l}\text { Bersedia Dengan } \\
\text { syarat }\end{array}$ & $\begin{array}{l}\text { Bersedia Tanpa } \\
\text { syarat }\end{array}$ & Total \\
\hline Sangat rendah & $3(100 \%)$ & $0(0 \%)$ & $0(0 \%)$ & $3(100 \%)$ \\
Rendah & $8(61,5 \%)$ & $5(38,5 \%)$ & $0(0 \%)$ & $13(100 \%)$ \\
Sedang & $4(40 \%)$ & $6(60 \%)$ & $0(0 \%)$ & $10(100 \%)$ \\
Tinggi & $0(0 \%)$ & $0(0 \%)$ & $4(100 \%)$ & $4(100 \%)$
\end{tabular}


Reny, F.O., et al., Kecemasan, Kesepian dan Persepsi terhadap Perkawinan Siri, KELUWIH: Jurnal Sosial dan Humaniora, Vol. 1(2), 93-101, Oktober 2020

Berdasarkan tabel tersebut, dapat diketahui bahwa semakin rendah tingkat persepsi terhadap perkawinan siri, semakin rendah pula tingkat kesediaan melakukan perkawinan siri. Begitu pula sebaliknya, semakin tinggi tingkat persepsi terhadap perkawinan siri, semakin tinggi pula tingkat kesediaan melakukan perkawinan siri.

Tabel 6

Tabulasi Silang Antara Jumlah Anak Yang Dimiliki Dengan Kesediaan Melakukan Perkawinan Siri

\begin{tabular}{cllll}
\hline $\begin{array}{c}\text { Jumlah anak } \\
\text { yang dimiliki }\end{array}$ & $\begin{array}{l}\text { Tidak } \\
\text { bersedia }\end{array}$ & $\begin{array}{c}\text { Kesediaan melakukan kawin siri } \\
\text { Bersedia }\end{array}$ & $\begin{array}{c}\text { Bersedia Tanpa } \\
\text { Dengan syarat }\end{array}$ & Total \\
\hline 0 & $2(50 \%)$ & $0(0 \%)$ & $2(50 \%)$ & $4(100 \%)$ \\
1 & $6(54,5 \%)$ & $5(45,5 \%)$ & $0(0 \%)$ & $11(100 \%)$ \\
2 & $5(45,5 \%)$ & $6(54,5 \%)$ & $0(0 \%)$ & $11(100 \%)$ \\
3 & $2(66,7 \%)$ & $0(0 \%)$ & $1(33,3 \%)$ & $3(100 \%)$ \\
4 & $0(0 \%)$ & $0(0 \%)$ & $1(100 \%)$ & $4(100 \%)$ \\
\hline
\end{tabular}

Berdasarkan tabel di atas diketahui bahwa jumlah anak yang dimiliki, semakin kecil pula tingkat kesediaan melakukan perkawinan siri. Begitu pula sebaliknya, semakin banyak jumlah anak yang dimiliki, semakin besar frekuensi kesediaan melakukan perkawinan siri.

Tabel 7

Tabulasi Silang Antara Jenis Dukungan Yang Didapatkan Dengan Kesediaan Melakukan Perkawinan Siri

\begin{tabular}{lllll}
\hline Jenis dukungan & Tidak bersedia & $\begin{array}{c}\text { Kesediaan melakukan kawin siri } \\
\text { Bersedia Dengan } \\
\text { syarat }\end{array}$ & $\begin{array}{c}\text { Bersedia Tanpa } \\
\text { syarat }\end{array}$ & Total \\
\hline $\begin{array}{l}\text { Tidak mendapat } \\
\text { dukungan }\end{array}$ & $0(0 \%)$ & $0(0 \%)$ & $1(100 \%)$ & $1(100 \%)$ \\
$\begin{array}{l}\text { Dukungan moral } \\
\begin{array}{l}\text { Dukungan moral } \\
\text { dan material }\end{array}\end{array}$ & $8(38,1 \%)$ & $10(47,6 \%)$ & $3(14 \%)$ & $21(100 \%)$ \\
\hline
\end{tabular}

Berdasarkan tabel di atas diketahui bahwa semakin lengkap dukungan (moral dan material) yang didapatkan subjek, semakin kecil potensi kesediaan melakukan perkawinan siri. Begitu juga sebaliknya, semakin tidak mendapatkan dukungan apapun baik dari pihak keluarga dan teman, semakin besar potensi subjek untuk bersedia melakukan perkawinan siri.

\section{BAHASAN}

Berdasarkan hasil statistik (Tabel 1), subjek mengalami kecemasan di level rendah (50\%) dan sedang (23.3\%). Sementara, persepsi perkawinan siri berada pada kategori yang sama, yaitu rendah (43.3\%) dan sedang (33.3\%). Namun setelah dilakukan uji hipotesis (Tabel 2), didapatkan hasil yang menunjukkan bahwa tinggi atau rendahnya tingkat kecemasan tidak diikuti dengan naik atau turunnya persepsi terhadap perkawinan siri. Tingkat kesepian yang dialami subjek (Tabel 2) berada pada kategori sedang (43.3\%) dan tinggi (26.7\%), namun hasil uji statistik menunjukkan tidak ada hubungan antara kesepian dengan persepsi terhadap perkawinan siri (Tabel 3).

Rendahnya tingkat kecemasan yang dialami oleh subjek menggambarkan bahwa $50 \%$ dari mereka berhasil menghadapi penyesuaian perceraian, sehingga tidak mengalami 
kecemasan yang berarti. Beberapa dampak kecemasan yang diduga akan dialami subjek penelitian seperti: menurunnya kapasitas kognitif individu ketika menyelesaikan masalah kehidupan yang kompleks (Suharnan 2005), performance yang menurun (Powell 2004), dan terganggunya hubungan sosial serta kecenderungan mengalami depresi tidak terjadi. Selain itu, $50 \%$ dari subjek merupakan karyawan tetap, sehingga selain mandiri secara finansial, subjek juga tidak mengalami ancaman untuk dikeluarkan sewaktu-waktu seperti pegawai kontrak. Kemandirian finansial yang dimiliki membuat subjek memiliki kepercayaan diri yang tinggi dan merasa layak untuk mendapatkan perkawinan yang sah dan resmi sesuai dengan Undangundang Perkawinan di Indonesia.

Dariyo (2008) menyatakan bahwa kecemasan pada janda disebabkan oleh kekhawatiran pada kemampuan diri ketika harus menghadapi masalah sendirian seperti memenuhi kebutuhan ekonomi keluarga, membesarkan dan mendidik anak-anak, serta khawatir tentang respon dari masyarakat tentang status barunya sebagai janda. Berdasarkan teori tersebut, didapatkan tiga posisi teratas yang menjadi sumber kecemasan janda pada penelitian ini, yakni: tumbuh kembang anak $(21.9 \%)$, biaya pendidikan dan masa depan anakanak (14.28\%) dan keinginan untuk menikah kembali (12.38\%). Tiga teratas sumber kecemasan berikutnya terkait kebutuhan sehari-hari $(11.43 \%)$, pandangan masyarakat tentang status janda, dan kesendirian di hari tua masing-masing sebanyak $9.52 \%$.

Seluruh subjek penelitian adalah wanita bekerja, 50\% karyawan tetap dan $50 \%$ sisanya adalah karyawan kontrak dan wiraswasta. Oleh karena itu, dapat dikatakan bahwa subjek pada penelitian ini masih menjalin relasi dengan orang lain meskipun mungkin ada yang hanya sebatas kolega bisnis. Meskipun demikian, mayoritas kesepian yang dialami subjek berada dalam kategori sedang dan tinggi (Tabel 1). Penelitian Lopata menyatakan bahwa kesepian pada janda dihubungkan dengan munculnya perasaan seperti hasrat untuk bersama suami, keinginan untuk dicintai oleh seseorang, keinginan untuk mencintai dan memperhatikan seseorang, keinginan untuk sharing dengan seseorang, keinginan untuk memiliki seseorang yang ada di sekitar rumah, membutuhkan seseorang untuk berbagi tugas, kerinduan dengan bentuk kehidupan sebelumnya, pengalaman atas hilangnya status perkawinan, pengalaman kehilangan pasangan, dan merasa tidak mampu menjalin hubungan baru (Miller et al., 2007). Merujuk teori Lopata, maka dapat disimpulkan bahwa kesepian pada janda lebih dikaitkan pada kerinduan akan hadirnya pasangan. Akibatnya, meski subjek masih menjalin relasi dengan teman kantor maupun teman bisnis, perasaan kesepian tidak dapat dihindari.

Shaver dan Peplau menyatakan bahwa orang yang merasa kesepian cenderung pasrah (desperate), yakni kehilangan harapan serta perasaan menyedihkan sehingga mampu melakukan tindakan nekat yang kurang mempedulikan bahaya bagi diri sendiri maupun orang lain (Miller et al., 2007). Hal ini menjadi tidak sesuai dengan teori ketika hasil penelitian menunjukkan tidak adanya hubungan antara kesepian dengan persepsi terhadap perkawinan siri. Dalam rangka mengungkap ketidaksesuaian tersebut, peneliti melakukan uji chi square terhadap variabel persepsi terhadap perkawinan siri, kesepian, dan kecemasan dengan variabel nominal yakni kesediaan melakukan kawin siri.

Hasil uji chi square (Tabel 4) menunjukkan bahwa terdapat asosiasi antara persepsi terhadap perkawinan siri dengan kesediaan melakukan kawin siri, jumlah anak yang dimiliki dengan kesediaan melakukan perkawinan siri, dan jenis dukungan yang didapatkan subjek dengan kesediaan melakukan perkawinan siri. Berdasarkan hasil tersebut, peneliti melakukan tabulasi silang dan mendapatkan data bahwa 50\% dari subjek menyatakan bersedia melakukan perkawinan siri (Tabel 5). Secara terperinci, 38.5\% subjek dengan tingkat persepsi terhadap perkawinan siri pada kategori rendah dan 60\% subjek pada kategori sedang bersedia melakukan perkawinan siri dengan syarat tertentu. Sementara $100 \%$ subjek dengan tingkat persepsi terhadap perkawinan siri pada kategori tinggi bersedia melakukan perkawinan siri tanpa syarat.

Subjek yang menunjukkan persepsi terhadap kawin siri berusaha menunjukkan kecenderungan sikap, namun bukan berarti tidak memikirkan perkawinan siri sebagai salah 
satu alternatif solusi. Meski secara kognitif subjek menyadari adanya potensi kerugian yang dapat dialami di kemudian hari akibat tidak adanya perlindungan hukum negara, namun sebagian subjek tetap bersedia melakukan kawin siri. Dengan adanya syarat yang menyertai pada kesediaan subjek untuk melakukan perkawinan siri, tampak bahwa subjek berusaha mengendalikan dampak negatif yang dapat ditimbulkan ketika memiliki intensi untuk melakukan kawin siri.

Psikologi Gestalt meyakini bahwa apa yang dialami individu akan memengaruhi segala sesuatu yang lain di dalam diri individu tersebut. Ketika individu tersebut berhadapan dengan sebuah masalah, akan muncul keadaan ketidakseimbangan kognitif yang mengandung unsur motivasional sehingga menyebabkan organisme berusaha untuk mendapatkan kembali sistem mentalnya (Hergenhahn \& Olson 2008).

Pada Tabel 6, hasil statistik menunjukkan persentase kesediaan melakukan perkawinan siri terus meningkat seiring dengan jumlah anak yang dimiliki. Sebanyak $45.5 \%$ janda dengan anak satu bersedia melakukan kawin siri dengan syarat, $54.5 \%$ dari janda dengan anak dua bersedia melakukan kawin siri dengan syarat. Sementara, 33.3\% dari janda dengan anak 3 dan $100 \%$ janda dengan anak 4 bersedia melakuka kawin siri tanpa syarat. Jenis dukungan yang didapatkan subjek juga memiliki asosiasi dengan kesediaan melakukan kawin siri. Sebanyak $12.5 \%$ janda yang mendapatkan dukungan moral dan material dari keluarga, serta $47 \%$ janda yang mendapatkan dukungan moral saja, bersedia melakukan kawin siri dengan syarat. Sedangkan janda yang tidak mendapatkan dukungan apapun dari keluarga, 100\% bersedia melakukan kawin siri.

\section{SIMPULAN}

Berdasarkan hasil dan bahasan tersebut dapat disimpulkan bahwa untuk mengaktualisasikan intensi ke dalam perilaku, dibutuhkan jangka waktu tertentu. Dalam penelitian ini, diduga lamanya individu menyandang status janda turut mempengaruhi ada atau tidaknya intensi terhadap perilaku perkawinan siri. Selain itu, gambaran norma subjektif, tokoh pemberi referensi atau hal-hal lain yang juga dapat membentuk adanya motivasi untuk melakukan perkawinan siri tidak ada dalam data penelitian ini. Berdasarkan temuan dan dugaan tersebut, terbuka peluang untuk melakukan penelitian terkait gambaran perilaku perkawinan siri berdasarkan sudut pandang Theory Planned behavior.

Kelebihan penelitian ini adalah belum ada penelitian terdahulu yang melakukan uji hubungan antara kecemasan dan kesepian terhadap persepsi perkawinan siri pada janda. Rujukan penelitian psikologi terkait perkawinan siri juga masih sangat terbatas. Kelemahan penelitian ini adalah, peneliti menemukan bahwa terdapat asosiasi antara jumlah anak dengan kesediaan melakukan kawin siri. Hal ini ditunjukkan dengan semakin meningkatnya jumlah kesediaan kawin siri seiring dengan jumlah anak yang dimiliki. Namun temuan ini tidak dapat mewakili populasi janda dengan jumlah anak yang sama karena terbatasnya jumlah subjek penelitian, yakni satu orang dengan anak tiga, dan satu orang dengan anak empat.

Kelemahan lainnya adalah terbatasnya jumlah referensi terkait kawin siri sehingga pembahasan penelitian sangat terbatas. Kesensitifan topik terkait kawin siri juga mempengaruhi terbatasnya jumlah subjek penelitian yang bersedia berpartisipasi. Akibatnya, peneliti hanya menggunakan kriteria janda yang ingin menikah lagi sebagai screening awal. Sekiranya tingkat kecemasan dan juga kesepian dijadikan sebagai screening awal sehingga mendapatkan subjek penelitian yang lebih homogen, maka terdapat potensi untuk mendapatkan hasil penelitian yang berbeda meskipun menggunakan variabel penelitian yang sama.

\section{PUSTAKA ACUAN}

Atkinson, R. C., Atkinson, R. L., Smith, E. E., \& Bem, D. J. (1990). Introduction to psychology (10 Edition). Harcourt Brace Jovanovich. 
Cavanaugh, J. C., \& Blanchard-Fields, F. (2011). Adult Development and aging. Engage Learning. Crawford, M. (2017). Transformation. Woman, gender \& psychology (3 Edition). McGraw Hill-Publishing Company.

Dagun, S. M. (2002). Psikologi Keluarga (peranan ayah dalam keluarga). Rineka Cipta.

Dariyo. (2008). Psikologi Perkembangan Dewasa Muda. Grasindo.

DeGenova, M. K. (2008). Intimate Relationship, Marriage \& Family (7 Edition). McGraw HillPublishing Company.

Fachrina, \& Anggraini, N. (2007). PENELITIAN DOSEN MUDA PENYESUAIAN KEMBALI (READJUSTMENT ) Dibiayai Oleh Direktorat Penelitian dan Pengabdian kepada. 1-15.

Fathudin, S. A., \& Fitria, V. (2015). Problematika Nikah Siri Dan Akibat Hukumnya Bagi Perempuan. Humaniora, 15(1), 1-22.

Hergenhahn, B. R., \& Olson, M. H. (2008). theories of learning.

Hope, S., Power, C., \& Rodgers, B. (1999). Does financial hardship account for elevated psychological distress in lone mothers? Social Science and Medicine, 49(12), 1637-1649. https://doi.org/10.1016/S0277-9536(99)00251-8

Hurlock, E. B. (1996). Psikologi Perkembangan (Edisi-5). Penerbit Erlangga.

Luthfi, M. M., \& Luthfy, R. M. (2010). Nikah Sirri (F. Mubarok (ed.)). Wacana IImiah Press.

Miller, R., Perlman, D., \& Brehm, S. S. (2007). Intimate Relationship (4 Edition). McGraw HillPublishing Company.

Peplau, L.A. \& Perlman, D. (1982). Loneliness: A Source book of Current Theaory Research and Therapy.New York: wileyInterscience.www.peplaulab.ucla.edu/publications_files/Peplau_perlman_82.pdf

Powell, D. H. (1983). Understanding Human Adjustment: Normal Adaptation Through Life Cycle.

Powell Association.

Powell, Douglas H. (2004). Treating individuals with debilitating performance anxiety: An introduction. Journal of Clinical Psychology, 60(8), 801-808. https://doi.org/10.1002/jclp.20038

Pudrovska, T., \& Carr, D. (2008). Psychological adjustment to divorce and widowhood in midand later life: do coping strategies and personality protect against psychological distress? Advances in Life Course Research, 13(08), 283-317. https://doi.org/10.1016/S10402608(08)00011-7

Pujihartati. (2010). Fenomena Nikah Siri di Kalangan Mahasiswa dan Dampaknya Terhadap Perempuan. Jurnal Sosiologi, 24(2010), 41-48.

Sari, R. H. (2012). 25 persen masyarakat indonesia melakukan nikah siri. Merdeka.Com. https://www.merdeka.com/peristiwa/25-persen-masyarakat-indonesia-melakukan-nikahsiri.html\#: :text=Artinya pernikahan ini tidak tercatat,persen\%2C dan NTB 54 persen.

Saxton, L. (1986). The Individual, Marriage and The Family. Wadsworth, Inc.

Singh, B., \& Kiran, U. V. (2013). Loneliness among elderly women. International Journal of Humanities and Social Science Invention, 2(2013), 10-14.

Spielberger, C. D., \& Sarason, I. C. (1989). Stress \& Anxiety. Hemisphere Publishing Cooperation.

Suharnan. (2005). Psikologi Kognitif. Srikandi.

Wijaya, M. A. (2015, March 19). Pengelola Situs Nikah Siri Online Terancam Pidana. Republika.Co.ld. https://republika.co.id/berita/koran/didaktika/15/03/19/nlg8wh36pengelola-situs-nikah-siri-terancam-pidana 